\title{
UM PERFIL DO PROFISSIONAL CONTÁBIL NA ATUALIDADE: ESTUDO COMPARATIVO ENTRE CONTEÚDO DE ENSINO E EXIGÊNCIAS DE MERCADO
}

\author{
A PROFILE OF TODAY'S ACCOUNTING PROFESSIONAL: \\ A COMPARATIVE STUDY OF \\ TEACHING CONTENTS AND MARKET REQUIREMENTS
}

Recebido em: 05/11/2011 Aprovado em: 19/01/2012

Avaliado pelo sistema double blind review

Editora Científica: Manolita Correia Lima

\section{MARCOS ANTONIO DE SOUZA marcosas@unisinos.br \\ CAROLINE DA SILVA VERGILINO \\ UNIVERSIDADE DO VALE DO RIO DOS SINOS}

RESUMO

O objetivo do estudo é investigar a aderência existente entre os conteúdos oferecidos por Instituições de Ensino Superior - IEs do Rio Grande do Sul - e os requisitos do mercado de trabalho do profissional contábil. Trata-se de uma pesquisa de caráter exploratório, com abordagem qualitativa e nuances quantitativas. A coleta de dados, feita no $2^{\circ}$ semestre de 2010 , utilizou questionário, endereçado aos coordenadores de cursos de Ciências Contábeis do Rs, e seleção de anúncios de trabalhos publicados por headhunters na Revista Exame [período de janeiro 2008 a dezembro 2009]. A análise das ofertas de trabalho revela a procura por profissionais que apresentem amplos conhecimentos técnicos, habilidades pessoais e atitudes inovadoras. De outra parte, o resultado da análise das matrizes curriculares detalhadas pelos coordenadores de curso evidencia existirem IES que não contemplam alguns conhecimentos básicos e várias competências requeridas pelo mercado. Além disso, os resultados indicam que as maiores divergências entre ensino e mercado concentram-se em habilidades pessoais e não técnicas.

Palavras-chaves: profissional contábil; mercado de trabalho; educação contábil.

\section{ABSTRACT}

This article aims to investigate the extent to which the teaching content offered by Higher Education Institutions (HEI) of Rio Grande do Sul (RS) comply with the demands of the market for accounting professionals. This comprises exploratory research using a qualitative approach with quantitative aspects. Data was collected in the 2 d half of 2010 through a questionnaire sent to the coordinators of university Accounting degrees offered in RS, and from a selection of job advertisements published by headhunters in the Revista Exame magazine [for the period January 2008 to December 2009]. Analyzing the job vacancies revealed a demand for professionals with extensive knowledge, skills and an innovative approach. On the other hand, the results of the detailed analysis of the curricula provided by the course coordinators showed that they do not include some basic knowledge and various skills required by the market. Moreover, the results indicate that the greatest differences between education and the market focus on personal and non-technical skills.

Keywords: accounting professional; labor market; accounting education. 


\section{INTRODUÇÃO}

Historicamente, a contabilidade surgiu para suprir a necessidade de os gestores terem um instrumento que permitisse conhecer, controlar, medir os resultados de suas negociações e dar suporte ao processo decisório (RIBEIRO, 2007). Ao trazer uma interpretação de mercado ao surgimento da contabilidade, Iudícibus (1993, p. 3I) destaca que: "Em termos de entendimento da evolução histórica da disciplina, é importante reconhecer que raramente o 'estado da arte' se adianta muito em relação ao grau de desenvolvimento econômico, institucional, e social das sociedades analisadas, em cada época". Assim, para Iudícibus (1993), o grau de desenvolvimento das teorias contábeis e de suas práticas está diretamente associado, em grande parte, ao grau de desenvolvimento comercial, social e institucional das sociedades. Para o mesmo autor, cabe ao profissional da contabilidade ser, talvez, o principal agente a alavancar o cumprimento das novas demandas, ou até mesmo se antecipar a elas.

Com base em tais entendimentos, é possível constatar que a evolução e o progresso econômico das sociedades aumentam o nível de exigências requeridas dos profissionais para atuarem nas empresas, o que acaba refletindo na necessidade de um sistema de ensino apto a tal formação. Peleias et al. (2007, p. 20) também tratam dessa questão e concluem que "[...] como consequência, são necessárias condições de ensino para a formação desses profissionais".

O papel das Instituições de Ensino Superior - IES - nesse processo de formação, tem como fundamento legal o Art. 43 da Lei de Diretrizes e Bases da Educação Nacional (LBD), nº 9.394/96. De fato, com base nessa lei, as IES assumem a finalidade de "formar diplomados nas diferentes áreas do conhecimento, aptos para inserção em setores profissionais e para a participação no desenvolvimento da sociedade brasileira e colaborar na sua formação contínua”. Tcheou (2002) acrescenta que é por meio de suas matrizes curriculares que as IES apresentam as disciplinas ministradas 
ao longo do curso, organizando-as em conteúdos que buscam suprir as necessidades e expectativas da sociedade e das empresas, que demandarão os conhecimentos desses profissionais.

A relevância do papel que as IEs exercem na formação profissional, além do cidadão, tem sido reconhecida em diversos estudos. Peleias et al. (2008) reconhecem que para cumprir seu papel, é necessário que as IES identifiquem as competências e habilidades requeridas pelo mercado, de forma que consigam ajustar as matrizes curriculares e conteúdos de seus cursos às demandas do mercado de trabalho.

Nesse contexto, no que se refere ao ensino superior de contabilidade, entende-se que as IES são responsáveis pela formação de profissionais preparados, com seus conhecimentos alinhados às exigências do mercado, apresentando as competências e habilidades necessárias para atuarem nas diferentes áreas que a profissão permite, tais como: controladoria, custos, auditoria, controller, consultor, diretor, gerente financeiro, etc. Esse entendimento também está presente no estudo de Pires (2008).

A globalização e a evolução tecnológica são fatores que vêm rapidamente transformando o ambiente de atuação das empresas. Com isso, profissionais das mais variadas áreas de atuação precisam refletir, constantemente, se suas capacitações e atuações estão condizentes com as novas exigências impostas pelo mercado globalizado (CORdeiro; DUARTE, 2006). Cardoso, Souza e Almeida (2006) destacam que a globalização e o advento da informática estão transformando, significativamente, a economia mundial, e que, diante de tal realidade, o profissional contábil deve acompanhar essas transformações, acumulando habilidades que efetivamente vão preparálo para atender as novas exigências que o mercado de trabalho demanda. Nessa transição, Marion e Santos (2000, p. II) afirmam que "estamos diante de nova etapa na área contábil, ou seja, a fase mecânica cedeu lugar à fase técnica que está cedendo lugar à fase da informação".

Esse maior nível de preparação profissional pode ser constatado pelo conteúdo das qualificações requeridas nos anúncios públicos de ofertas de 
vagas na área. É comum, nesse processo de seleção, a utilização de empresas especializadas, as headhunters, para selecionar profissionais de talento e preparados para atenderem as reais necessidades dos empregadores.

Diante dessa breve contextualização do tema, emerge o seguinte problema de pesquisa: os conteúdos curriculares de instituições gaúchas de ensino superior, utilizados na formação dos contadores, sugerem consistências com as competências e habilidades atualmente exigidas pelo mercado de trabalho? Assim, o objetivo geral do estudo envolve analisar se as possíveis consistências com as competências e habilidades demandadas pelo mercado de trabalho estão sendo atendidas pelo conteúdo do conjunto de disciplinas e atividades que estruturam os cursos de graduação de Ciências Contábeis das IEs do Rio Grande do Sul.

Atualmente, tornam-se relevantes as discussões relacionadas à caracterização e à adequação no perfil do contador, de maneira que ele esteja efetivamente preparado para atender as exigências pertinentes às suas atividades profissionais. Essa relevância é reconhecida por diversos pesquisadores que têm tratado do tema, a exemplo de Consenza (200I), Cardoso, Souza e Almeida (2006), Ribeiro (2007), Peleias et al. (2008). Para os autores, o contador moderno deve dominar todas as competências e habilidades que permeiam a profissão, porém, de forma contextualizada e com visão nas diversas relações com outras áreas de conhecimento; além disso, ele também deve ser visto como um comunicador de informações essenciais à tomada de decisões. Essas duas caracterizações parecem suficientes para justificar que é relevante investigar se a formação acadêmica do futuro profissional de contabilidade, propiciada pelas IES, está ocorrendo de forma consistente a elas.

Os benefícios e resultados deste estudo podem atender a diversas dimensões: (a) para aqueles que desejam atuar na área contábil, o estudo pode ser útil no momento de se decidir qual instituição de ensino superior está com seu conteúdo mais alinhado com as competências e habilidades exigidas pelas empresas; (b) para os coordenadores acadêmicos, gestores de cursos ministrados IES, o estudo oferece a oportunidade de avaliarem se seus cursos estão formando profissionais capacitados a atuarem no mercado 
de trabalho ou se mudanças devem ser consideradas; (c) para os que já são profissionais, pode ser útil como uma autoavaliação e análise, se estão efetivamente preparados para atenderem as atuais exigências das empresas e, caso necessário, buscar alternativas de superarem possíveis deficiências. Além desta introdução, o estudo contempla outras quatro seções. A primeira delas corresponde à contextualização teórica do tema; na segunda, o destaque é dos principais aspectos metodológicos da pesquisa; a terceira concentra-se na apresentação, análise e discussão dos dados e resultados. Por fim, tem-se a conclusão do estudo, seguida da lista das referências utilizadas na sua construção. 


\section{REFERENCIAL TEÓRICO}

\section{CRIAÇÃO DO CURSO SUPERIOR DE CIÊNCIAS CONTÁBEIS}

Da mesma forma como ocorre em outras áreas de conhecimento, o estágio atual da contabilidade também é fruto de diversas modificações ocorridas ao longo do tempo. Ao tratar dessas modificações, Leite (2005) destaca que, em 1942, ocorreu uma reforma nas distintas ramificações do ensino, denominada Leis Orgânicas do Ensino, também conhecida como Reforma de Capanema. Essa reforma promoveu diversas alterações nas estruturas curriculares dos cursos secundários e profissionalizantes, motivadas pelos seguintes fatos: (a) o ensino comercial, até o final da Primeira República, não se apresentava de forma organizada no país; (b) a necessidade de atualização das matrizes curriculares dos cursos existentes; (c) o processo de industrialização impunha novas exigências econômicas; (d) acentuado crescimento tanto no número de alunos matriculados quanto no número de escolas de ensino comercial.

Ainda de acordo com Leite (2005), o curso de Contabilidade, anteriormente ofertado como curso técnico de guarda-livros, teve sua matriz curricular modificada e ampliada, ou seja, o curso passou de dois para três anos de duração em função do aumento no número de disciplinas exigidas para a conclusão do curso. Contudo, aos concluintes do curso ainda era concedido um diploma de guarda-livros.

O aumento no número de disciplinas, e, consequentemente, do tempo de duração do curso, visava a preparar o aluno para ingressar num curso de nível superior. Porém, mesmo sem intenção, o curso acabou despertando o interesse dos trabalhadores, que se tornaram seus principais clientes na busca de uma efetiva forma de melhorarsuas condições de vida.

O Decreto Lei nº. 6.I4I, de 28/12/1943, extinguiu os cursos para atuários e contadores, dando aos alunos do curso técnico comercial o direito de ingressarem nos cursos de nível superior, desde que esse curso estivesse diretamente relacionado com o curso comercial técnico concluído. Isso ocorreu, segundo Leite (2005), porque, até então, os concluintes desse curso 
técnico só tinham a opção de ingressar no curso superior de administração e finanças.

De acordo com Peleias et al. (2007), é nesse ambiente de mudanças que surge o curso Superior de Ciências Contábeis e Atuariais, por meio do Decreto $n^{\circ}$ 7.988, de 22-09-1945. O objetivo era melhor preparar os seus concluintes para bem atenderem as novas exigências econômicas do país. $\mathrm{O}$ curso tinha duração de quatro anos e concedia um diploma de Bacharel em Ciências Contábeis aos concluintes. A matriz curricular de ensino objetivava a formação de profissionais tecnicamente capacitados para atenderem apenas as perspectivas da época, não demonstrando interesse na formação "de um profissional pesquisador, questionador, criativo" (LEITE, 2005, p. II2).

Essa criação do curso superior em contabilidade desencadeou a reivindicação dos contadores sobre o governo federal, visando à criação de um órgão que cuidasse da classe contábil. Assim, por meio do Decreto Lei $\mathrm{n}^{\mathrm{o}}$ 9.295, de 27-05-1946, criou-se o Conselho Federal de Contabilidade (CFC) e foram definidas as atribuições do contador e do técnico em contabilidade.

\section{ENSINO CONTÁBIL NA ATUALIDADE}

Até hoje, as matrizes curriculares utilizadas nas IES ainda são organizadas com base na Resolução 03/92 do Conselho Federal de Educação.

Segundo Leite (2005), a Resolução 3/92, entre outras deliberações, definiu que o curso seria dividido em três categorias: (a) a categoria I engloba disciplinas de formação geral e de natureza humanística e social; (b) a categoria II compreende disciplinas que desenvolvam conhecimentos para a formação profissional tais como: conhecimentos para a formação profissional básica, específica e outras a critério da instituição; (c) a categoria III correspondente a disciplinas que desenvolvam o conhecimento ou atividades de formação complementar, podendo ser: computação, jogos de empresas, estudo de caso, estágio supervisionado, trabalho de conclusão de curso, entre outros.

Laffin (2007) considera que o tema educação contábil é constantemente discutido no meio acadêmico porque é visível que as matrizes curriculares precisam ser reformuladas. É preciso encontrar um eixo norteador, por 
meio da criação de um projeto pedagógico, que integre os conteúdos de forma que os conhecimentos a serem transmitidos organizem a abrangência e permitam a compreensão da totalidade do curso, voltados a suprir as necessidades do mercado de trabalho.

A questão da qualidade do ensino em contabilidade também foi tratada por Nascimento (2005), realizado com IES paranaenses, nas quais foi identificada a necessidade de maiores avanços qualitativos. Ott et al. (20II) trazem um estudo comparativo internacional, abordando a percepção de profissionais e estudantes americanos, brasileiros e chineses quanto a três dimensões (conhecimentos, habilidades e métodos de ensino-aprendizagem). Foi identificado maior nível de importância, percebida das dimensões pelos profissionais em relação aos estudantes. Comparativamente aos chineses, os brasileiros atribuem maior importância para as três dimensões analisadas.

\section{PROFISSÃO CONTÁBIL}

\section{Atuação e Tendências da Profissão Contábil}

A atividade básica do Contador é registrar, mensurar e controlar fatos econômicos e financeiros sobre as variações patrimoniais da empresa. Com base nos dados daí resultantes, e utilizando processos específicos, transforma-os em informações transmitidas por meio de relatórios e demonstrativos que sejam úteis aos usuários da Contabilidade. Portanto, a função básica desse profissional é atender os gestores na tomada de decisões e demonstrar a situação patrimonial da empresa aos acionistas, fornecedores, clientes, governo, entre outros usuários (MORAES; MADEIRA, 2002).

Esse entendimento corrobora a interpretação dada por Attie (1998), para o qual o contador é responsável pela produção de informativos de controle que apresentem dados e informações referentes a eventos econômicos ocorridos e que tenham, ou que possam ter impactos diretos ou indiretos no patrimônio da empresa. Além disso, os informativos devem atender as necessidades de diferentes usuários internos e resguardar os interesses dos usuários externos. 
Adicionalmente a esse entendimento de Attie, estudos contemporâneos a ele (MARION, I998; PEREIRA FILHO, I999) já advogavam que as empresas começavam a perceber que, numa economia cada vez mais exigente e competitiva, existia a necessidade de um profissional que atuasse como fornecedor e intérprete de informações necessárias ao processo decisório. Nota-se, portanto, que um leque de oportunidades se abria para que os profissionais da área contábil pudessem participar de forma mais objetiva da gestão das empresas, mesmo que de forma indireta via disponibilização de informações gerenciais, além daquelas de amplitudes fiscais já tradicionalmente produzidas. Silva (2008, p. 2) acrescenta que "com a contínua evolução das mudanças no cenário mundial introduzidas pela globalização e, consequentemente, maior velocidade na obtenção de informações", é imprescindível que o contador se conscientize de que sua verdadeira função esta além da contabilidade tradicional.

Pires (2008) corrobora tal entendimento e identifica diversas áreas que oportunizam a atuação do profissional contábil, principalmente aquelas em que a contabilidade vai influenciar diretamente, auxiliando os gestores na tomada de decisões. Entre os possíveis campos de atuação do contador, Mansouri, Pirayesch e Salehi (2009) abordam as atividades de auditoria independente e discutem questões relacionadas à competência e à qualidade do serviço executado. Em função do amplo mercado, Schwez (200I) indica que o contador moderno não se concentra somente na ideia da contabilidade tradicional, mais centrada em suprir as necessidades fiscais e legais. $\mathrm{Na}$ realidade, ele se aprimora para ser o profissional que analisa as informações, esclarece dúvidas, orienta gestores e auxilia na tomada de decisões. Dada essa diversidade de atuação do profissional, Ribeiro (2007, p. 2) destaca que "o perfil do contador moderno é de uma pessoa que acumula conhecimentos sociais e técnicos em função do amplo mercado que ele tem à sua disposição".

Além dos estudos já citados, outros têm sido desenvolvidos no intuito de discutir as várias amplitudes e oportunidades do campo de atuação do profissional contábil. Essas diversas abordagens são encontradas, por exemplo, nos trabalhos de Burns e Baldvinsdottir (2005), Byrne e Pierce (2007), Albu et al. (2008; 201I). Todos esses estudos apresentam algo em 
comum, ou seja, a discussão das novas perspectivas e dos novos papéis disponíveis para avanços na atividade profissional em questão. Também é de presença contínua a abordagem das exigências, competências e habilidades, que a realidade de mercados mais competitivos impõe a esse profissional da contabilidade.

\section{Competências Requeridas no Perfil do Novo Profissional Contábil}

Como mencionado na seção anterior, em função do aumento da concorrência, da globalização, da velocidade e facilidade de obtenção de informações, as empresas, que pretendem continuar competitivas no mundo dos negócios, precisam ter uma contabilidade adequada, ou seja, um profissional contábil preparado a atender as novas demandas. Para isso, é importante que ele esteja disposto a adquirir e manter as competências e habilidades necessárias para atender as exigências de um mercado que se mostra cada vez mais competitivo e veloz na mudança de cenários estratégicos, operacionais e econômicos.

Com base nesse contexto, a discussão sobre o perfil do contador passa pelo entendimento do significado que competências e habilidades têm na construção do conhecimento e da atuação desse profissional. A compreensão e aplicação desses termos, entretanto, devem ser feitas com restrições e delimitadas a situações específicas, dado que uma definição de aplicação irrestrita a todas as situações tem utilidade discutível. Para Perrenoud (1999, p. 19), um dos destacados pesquisadores dessa temática, "não existe uma definição clara e partilhada de competências. A palavra tem muitos significados e ninguém pode pretender dar a definição". Esse entendimento é compartilhado por outros autores pesquisados (ROPÉ; TANGUY, I997; MACEDO, I999; WESTERA, 200I; ROE, 2002; VALENTE, 2003; TEODORESCU, 2006).

Apesar dessas limitações, para Roe (2002), há um grande consenso na literatura, que define competência como a habilidade aprendida para adequadamente desempenhar uma tarefa. Esse entendimento de ROE corrobora Perrenoud (2000), para o qual competência é a faculdade que se tem para mobilizar um conjunto de recursos cognitivos como saberes, habilidades e informações, a fim de solucionar com pertinência e eficácia 
uma série de situações. Braslavsky (1999) também se posiciona dessa forma, enfatizando que pessoas competentes são aquelas capazes de resolver situações problemas de maneira satisfatória, que sabem como agir perante o inesperado. Tem-se, baseada nesses entendimentos, que, enquanto a habilidade é o saber fazer ou realizar algo (classificar, registrar, mensurar, reportar etc), a competência reflete a capacidade de o indivíduo mobilizar suas habilidades, conhecimentos e atitudes para solucionar determinada situação problema. Assim, ao invés de tratar competências e habilidades como conceitos opostos, o autor sugere o reconhecimento delas como elementos que se completam e interagem.

Especificamente direcionado aos contabilistas, foi realizado sob o patrocínio da Associação Americana de Certificação de Contadores Públicos (AICPA), no âmbito da educação contábil, o estudo desenvolvido por Wolcott, Baril e Cunningham (2000). Tal estudo faz uma análise do nível de complexidade requerida pelas competências na atividade contábil, em seus mais diversos níveis de atuação, e das habilidades necessárias para a solução dos problemas relacionados.

Outros pesquisadores têm se dedicado ao exame dessas questões do perfil do profissional contábil. Luft (2000, p. I82) amplia os conteúdos já apresentados e esclarece que competência é "... idoneidade, aptidão, habilidade, saber" e habilidade é “... capacidade, inteligência”. Para Kounrozan (2005, p. 4), competência é a aquisição do conhecimento técnico essencial, e habilidade é "a capacidade de transmissão e análise do conteúdo técnico". Cordeiro e Duarte (2006) consideram que para o profissional contábil tornar-se apto para suprir as necessidades impostas pelo mercado, deve ele ampliar seus conhecimentos específicos, tornando-se gestor da informação contábil e apresentando um conjunto de habilidades que englobam: iniciativa, ética, visão de futuro, habilidade de negociação, flexibilidade e capacidade de inovar e criar. Schwez (200I) complementa que o profissional contábil do novo milênio apresentará como diferencial a imagem de uma pessoa bem informada, dinâmica, bom intérprete e comunicador das informações.

Para Schwez (2000, p. I2), o contador moderno deverá aprender novas linguagens e tecnologias, ter iniciativa, imaginação, sensibilidade, ser 
inovador, questionador, flexível, corajoso, audacioso, acreditar nos seus sonhos e, acima de tudo, ser consciente de que "o aprendizado permanente é a chave para a sobrevivência".

Kounrozan (2005) enfatiza que para desempenhar as funções atualmente exigidas pelo mercado o contador deve entender e conhecer, de forma global, as tendências econômicas, políticas, sociais e culturais; conhecer o segmento do mercado em que esteja inserido; conhecer o processo operacional da empresa, conhecer normas e princípios contábeis; ter capacidade para o desenvolvimento, análise e implantação de sistemas de informação contábil e de controle gerencial; ter a capacidade de comunicar-se de forma escrita ou verbal; ser capaz de escutar opiniões opostas, trabalhar sob pressão, delegar atividades, organizar, motivar e desenvolver a equipe; ser criativo e persuasivo. Esses requisitos para a função contábil estão contemplados na Resolução 6/2004, de Io de março de 2004, editada pela Câmara de Educação Superior do Conselho Nacional de Educação, referente à instituição de diretrizes curriculares nacionais dos cursos de Ciências Contábeis.

Diante dessa realidade, o contador deve ter consciência de que se manter atualizado e em constante aperfeiçoamento são as únicas formas de se destacar no mercado atual. Enfim, o contador deve se preocupar em dominar os requisitos de competência e habilidades que a sua atividade requer para bem cumprir as metas estabelecidas. 


\section{METODOLOGIA}

\section{CLASSIFICAÇÃO DA PESQUISA}

A pesquisa pode ser classificada, segundo Silva (2006), em três categorias: quanto à abordagem do problema, quanto aos objetivos, e quanto aos procedimentos técnicos.

Quanto à natureza ou abordagem do problema, a pesquisa é classificada como qualitativa com nuances quantitativas; exploratória quanto aos objetivos; e documental e survey quanto aos procedimentos técnicos.

Apesar de não utilizar recursos e técnicas estatísticas mais específicas e aprofundadas, a pesquisa contém nuances quantitativas dada a utilização de quantificações numéricas (frequências e porcentagens) para tratar e analisar os dados coletados (RICHARDON, I999).

Enquadra-se como exploratória, pois, conforme Gil (I999, p. 43), é desenvolvidas "com o objetivo de proporcionar visão geral, de tipo aproximativo, acerca de determinado fato". Tal fato, neste caso, refere-se às possíveis consistências entre as competências e habilidades requeridas nas ofertas de empregos em relação àquelas disponibilizadas pelo ensino na formação acadêmica.

A pesquisa é classificada também como documental porque utiliza os anúncios de empregos (dados secundários), publicados por headhunters, para profissionais graduados em ciências contábeis coletados na Revista Exame, nos anos de 2008 e 2009. Já a classificação survey decorre da coleta de dados processada mediante a aplicação de questionários respondidos pelos coordenadores de cursos de Ciências Contábeis das IES pesquisadas (dados primários).

\section{POPULAÇÃO E AMOSTRA}

\section{As Ofertas de Emprego}

Segundo Silva (2006, p. 73), a população de pesquisa “é o conjunto de seres animados ou inanimados que apresentam, pelo menos, uma característica 
em comum" e a amostra corresponde a uma "parcela, convenientemente selecionada da população de pesquisa”.

Para esta pesquisa a população é composta pelos anúncios de emprego, ofertadas por meio de headhunters, publicadas na Revista Exame, nos anos de 2008 e 2009. Dessa forma, a população da pesquisa é composta por I.I29 anúncios de emprego, dos quais $73,9 \%$ se apresentam concentrados na empresa Michael Page e II,9\% na empresa Hays Human Resources.

Dado o objetivo estabelecido, para os fins desta pesquisa interessam apenas as ofertas de trabalho que tenham como foco profissionais relacionados a atividades da área contábil. Portanto, não apenas, mas com destaque para graduados em Ciências Contábeis. Diante dessa premissa, a população se reduziu significativamente, em 95,3\%, redundando em 53 anúncios de emprego. Apresenta-se na Tabela I a lista completa das headhunters anunciantes.

Tabela 1 Empresas headhunters Anunciantes

\begin{tabular}{|llll|}
\hline & \multicolumn{2}{l}{ Número de Anúncios } & \\
\hline Empresas & Total Analisados & Área Contábil & $\%$ \\
\hline Haye Human Resources & 134 & 20 & 1,8 \\
\hline Michael Page & 834 & 13 & 1,1 \\
\hline Page Personnel & 34 & 7 & 0,6 \\
\hline Robert Half & 4 & 1 & 0,1 \\
\hline Manager Assessoria & 67 & 8 & 0,7 \\
\hline Viva Talentos Humanos & 1 & 1 & 0,1 \\
\hline Ricardo Xavier & 55 & 3 & 0,3 \\
\hline Total & $\mathbf{1 . 1 2 9}$ & $\mathbf{5 3}$ & $\mathbf{4 , 7}$ \\
\hline
\end{tabular}

\section{Instituições de Ensino Superior}

Outro elemento que compõe a amostra da pesquisa é a parcela da população de 43 IEs situadas no Rio Grande do Sul e que oferecem o curso de graduação em Ciências Contábeis. Identificou-se que a existência de vários campi de uma mesma ies provoca um número maior de cursos, desconsiderado nesta pesquisa já que aqui o foco é a instituição e não um campus em particular. Além disso, a estrutura curricular dos cursos tende a ser a 
mesma, independentemente dos vários campi de uma mesma IES.

Ao final da coleta de dados, a amostra ficou composta por 2I instituições que responderam ao questionário, equivalente a $48,8 \%$ da população. As IES participantes estão estabelecidas em I7 diferentes municípios do estado do Rs. Observa-se que apesar da confirmação de participação quando do contato inicial, no momento da efetiva coleta de dados 20 coordenadores não responderam o questionário e apenas dois justificaram a não participação como decorrência de outras prioridades internas (Tabela 2).

Tabela 2 Participação de Coordenadores de Cursos na Pesquisa

\begin{tabular}{|lll|}
\hline Coordenadores que responderam ao questionário & Quantidade de IES & $\%$ \\
\hline Coordenadores que justificaram sua não participação & 21 & 48,8 \\
\hline Coordenadores que não se manifestaram & 2 & 4,7 \\
\hline Total & 20 & 46,5 \\
\hline Viva Talentos Humanos & 43 & 100 \\
\hline Ricardo Xavier & 1 & 1 \\
\hline Total & 55 & 3 \\
\hline & $\mathbf{1 . 1 2 9}$ & $\mathbf{5 3}$ \\
\hline
\end{tabular}

\section{COLETA DE DADOS}

Para atender aos objetivos propostos nesse estudo, os dados foram coletados das seguintes formas: (a) da Revista Exame foram analisadas todas as ofertas de trabalho, publicadas pelos headhunters nos anos de 2008 e 2009, das quais foram extraídas aquelas destinadas aos profissionais da área contábil; (b) pesquisa no site (MEC/e-MEC) para identificação das IEs situadas no Rio Grande do Sul, que oferecem o curso de graduação em Ciências Contábeis; (c) as disciplinas que compõem os currículos utilizados pelas instituições de ensino superior do curso de Ciências Contábeis, via sítios dos respectivos cursos.

No que se refere aos currículos do curso de Ciências Contábeis, a coleta de dados foi realizada por meio de questionário encaminhado por e-mail aos coordenadores dos cursos de graduação em Ciências Contábeis das IES situadas no Rio Grande do Sul. Os endereços eletrônicos dos coordenadores 
foram obtidos por meio de pesquisa realizada aos sítios das instituições e por meio de ligações telefônicas às respectivas secretarias de graduação. $\mathrm{O}$ envio dos e-mails com questionários se repetiu até a obtenção de um número razoavelmente representativo (23 respostas).

Para construção do questionário fez-se a descrição das competências e habilidades requeridas dos possíveis candidatos às ofertas de emprego. Espaço em branco foi disponibilizado para o coordenador apontar a disciplina que contemplava o conteúdo requerido nos anúncios e o semestre do curso onde ela era oferecida. Com base nessas informações, pode-se verificar a existência, ou não, de consistência do conteúdo das IEs com aquele requerido pelas ofertas.

\section{TÉCNICAS E PROCESSO DE ANÁLISE}

A análise de dados, conforme Silva (2006, p. 66), consiste na utilização de um conjunto de técnicas de análise do conteúdo das comunicações, realizada "por meio de categorias sistemáticas previamente determinadas, que podem levar a resultados quantitativos". Por esta razão, a técnica de análise de conteúdo foi utilizada no estudo.

Como descrito na seção anterior, em um primeiro momento, a identificação das competências e habilidades requeridas pelo mercado foram analisadas isoladamente. Esta análise resultou no questionário que serviu como instrumento para a coleta dos dados referentes às matrizes curriculares utilizadas pela IEs pesquisadas.

Posteriormente, após a identificação das competências e habilidades requeridas pelo mercado e daquelas desenvolvidas pelas instituições de ensino superior, fez-se uma comparação, com cálculo das respectivas frequências o que possibilitou verificar a existência de alinhamentos entre os dois conteúdos. 


\section{LIMITAÇÕES DO ESTUDO}

Conhecer as limitações do estudo é importante para ser possível avaliar as metas estabelecidas e as alcançadas (CEDRO, 20II). Nesse sentido, dados os procedimentos adotados na elaboração deste estudo, algumas limitações devem ser observadas.

Uma limitação corresponde à utilização do coordenador de curso como fonte de dados coletados nas ies. Apesar dessa limitação de fonte única, entende-se que o coordenador é a pessoa que melhor reúne a consolidação dos conteúdos tratados nos cursos. Além disso, quando possível, solicitou-se a ele a participação dos respectivos professores na resposta dos questionários. De qualquer forma, e mesmo com essa participação dos professores, maior segurança quanto aos conteúdos ministrados careceriam, ainda, da também participação dos discentes. Talvez em estudos mais restritos, na modalidade de estudos de casos, tal estratégia metodológica seja mais viável.

Outra limitação a destacar refere-se à não utilização de técnicas estatísticas mais avançadas. De fato, o estudo limitou-se à utilização de frequências percentuais. Dado o propósito do estudo em verificar o possível alinhamento entre mercado e ensino, considerou-se que esta simplificação atenderia a avaliação exploratória, que se pretendeu realizar. Deve-se reconhecer, entretanto, que, em estudos que objetivem maior profundidade de análise, uma exploração quantitativa mais robusta pode trazer informações adicionais para análise.

Há também a limitação de se considerar os conteúdos das ofertas como representantes do mercado de emprego para a área contábil. Isso ocorre, porque, como é prática, há também anúncios de empregos veiculados diretamente por empresas.

Por último, destaca-se que a pesquisa concentrou-se exclusivamente nos conteúdos específicos exigidos dos profissionais contábeis, não explorando a função da escola em formar cidadãos cientes de seus direitos e deveres para uma harmônica vida em sociedade, conforme tratado por Fogaça (1998) e Gondin (2002). 


\section{APRESENTAÇÃO E ANÁLISE DOS DADOS}

\section{PERFIL DAS INSTITUIÇÕES DE ENSINO SUPERIOR}

A classificação das IEs foi realizada com base na quantidade de questionários recebidos, ou seja, das 2I instituições que participaram do estudo. A classificação das IEs, de acordo com a sua natureza jurídica, é apresentada na Tabela 3.

Tabela 3 IEs classificadas conforme sua natureza jurídica.

\begin{tabular}{|c|c|c|c|}
\hline \multicolumn{2}{|l|}{ Natureza Jurídica } & Quantidade de IES & $\%$ \\
\hline \multicolumn{2}{|c|}{ Direito Público - Federal } & 2 & 9,5 \\
\hline \multicolumn{2}{|c|}{ Direito privado, Com fins lucrativos } & 3 & 14,3 \\
\hline \multirow{2}{*}{$\begin{array}{l}\text { Direto privado, } \\
\text { Sem fins lucrativos }\end{array}$} & Confessional & 7 & 33,4 \\
\hline & Comunitária & 9 & 42,8 \\
\hline \multicolumn{2}{|l|}{ Total } & 21 & 100 \\
\hline
\end{tabular}

Percebe-se que a maioria das IEs que participam da pesquisa é de direito privado, sem fins lucrativos $(76,2 \%)$, distribuídas entre Confessionais $(33,4 \%)$ e Comunitárias (42,8\%). A participação de outros tipos de IEs é minoritária, abrangendo 9,5\% de IEs Públicas Federais e I4,3\% de IEs Privadas com fins lucrativos. Essa minoritária participação das IEs públicas também tem sido identificada em outros estudos relacionados (NASCIMENTO, 2005).

\section{PERFIL DOS ANÚNCIOS DE EMPREGO}

\section{Apresentação das Ofertas de Trabalho}

A característica geral do mercado foi analisada em função da obrigatoriedade de graduação no curso de Ciências Contábeis.

Foram identificados 36 cargos disponíveis, os quais foram divididos por área de atuação, resultando em seis grupos distintos. Ressalta-se que o número total de cargos não corresponde ao número total de ofertas de 
trabalho utilizados para definir a amostra visto que as denominações dos cargos repetem-se em alguns anúncios (Quadro I).

Quadro 1 Ofertas de Trabalho

\begin{tabular}{|c|c|c|}
\hline Grupos & Principais Áreas de Atuação & Cargos \\
\hline 1 & Tributária & $\begin{array}{l}\text { Gerente de Impostos; } \\
\text { Gerente de Impostos Indiretos; } \\
\text { Gerente de Consultoria Tributária; } \\
\text { Gerente Fiscal e Planejamento Tributário; } \\
\text { Analista Fiscal Sênior; } \\
\text { Especialista Tributário Sênior; } \\
\text { Especialista Tributário }\end{array}$ \\
\hline 2 & Custos & Analista Financeiro de Planejamento \\
\hline 3 & Auditoria & $\begin{array}{l}\text { Auditor Interno; } \\
\text { Auditor Externo Sênior; } \\
\text { Gerente de Auditoria Externa }\end{array}$ \\
\hline 4 & Contabilidade & $\begin{array}{l}\text { Contador; } \\
\text { Consultor Contábil; } \\
\text { Coordenador Contábil; } \\
\text { Supervisor Contábil; } \\
\text { Gerente Contábil Fiscal; } \\
\text { Analista Contábil Sênior }\end{array}$ \\
\hline 5 & Controladoria & $\begin{array}{l}\text { Controller; } \\
\text { Controller de Negócio; } \\
\text { Controller de Planta; } \\
\text { Controller Financeiro Sênior; } \\
\text { Controller Regional; } \\
\text { Gerente de Planejamento Financeiro; } \\
\text { Especialista Econômico Financeiro; } \\
\text { Analista de Controladoria Pleno; } \\
\text { Analista de Controladoria Sênior; } \\
\text { Analista de Controles Internos; } \\
\text { Analista de Planejamento Pleno; } \\
\text { Assistente de Controller Sênior; } \\
\text { Assistente de Controller }\end{array}$ \\
\hline 6 & Financeira & $\begin{array}{l}\text { Diretor Financeiro; } \\
\text { Gerente Financeiro; } \\
\text { Gerente Administrativo Financeiro; } \\
\text { Analista/Especialista Financeiro; } \\
\text { Assistente de Contabilidade de Fundos; } \\
\text { Finanças }\end{array}$ \\
\hline
\end{tabular}

Os resultados encontrados demonstram que, dentro das áreas de atuação identificadas, os títulos dos cargos ofertados apresentam significativas variações terminológicas. 
No que diz respeito à hierarquia de contratação dos anúncios, $30 \%$ estão destinados ao nível de chefia, seguidos de $23 \%$ para gerência, $15 \%$ para analista, $13 \%$ para assistente, $6 \%$ para especialista, $4 \%$ para diretoria, $4 \%$ para coordenador, $4 \%$ para profissional independente e $2 \%$ para posição de supervisor. Apesar das variações, observa-se a majoritária contratação de pessoal em nível de comando superior, justificando inclusive a presença das headhunters.

\section{Competências e Habilidades Requeridos por Grupos de Área de Atuação} Durante a coleta de dados, identificou-se que para ocupação dos cargos, anteriormente citados, há diversos requisitos. Observa-se que o mercado requer 42 conhecimentos técnicos e 13 habilidades pessoais. Os conhecimentos técnicos foram classificados de acordo com os grupos por área de atuação, ou seja, seis grupos. Além disso, para reunir as habilidades pessoais requeridas pelo mercado foi criado o sétimo grupo, denominado Outras Habilidades.

Quadro 2 Conhecimentos Relativos ao Grupo 1: Área Tributária

Conhecimento das rotinas contábil e fiscal; Conciliar, analisar e apurar impostos diretos e indiretos, além do cumprimento das obrigações acessórias; Conhecimentos em IR, CS, PIS, COFINS, DIPJ; Conhecimento da tributação da zona livre de comércio de Manaus; Cálculo de impostos/taxas/ tributos, coletas e relatórios de último prazo; Conhecimento da legislação referente a impostos diretos e indiretos.

Para atuar na área tributária é necessário desenvolver os conhecimentos básicos (rotinas) relativos a Ciências Contábeis e à legislação tributária das diversas esferas.

Quadro 3 Conhecimentos Relativos ao Grupo 2: Área de Custos Controle dos custos das mercadorias e despesas operacionais; Conhecimentos em custo padrão; Apuração de custo das mercadorias; Controle de estoques.

Observa-se que os conhecimentos relativos à área de custos são colocados de forma bastante sumária e vinculada a procedimentos básicos e tradicionais. 
Assim, há ausência de práticas de custos mais avançadas sob o aspecto gerencial e mesmo estratégico.

Quadro 4 Conhecimentos Relativos ao Grupo 3: Auditoria

Domínio na utilização da USGAAP, BRGAAP, IFRS (consolidação, análise, conversão, relatórios para investidores estrangeiros); Garantir a conformidade de procedimentos e requisitos com a regulação Sarbanes-Oxley; Conhecimento das normas da Comissão de valores Mobiliários (CVM); Conhecimentos gerais sobre normas do Banco Central (BACEN) e Receita Federal; Implantação de práticas corporativas; Noções de FAS109; Conhecimentos em Legislação Societária..

Os conhecimentos requeridos para atuar na área de auditoria são coerentes com o cenário econômico atual, no qual se tem a abertura do comércio internacional, a busca por uma harmonização entre as normas nacionais e internacionais, o crescente número de empresas estrangeiras que se instalam no país.

O conhecimento em legislação societária e regulatória (CVM e BACEN) é pré-requisito para o exercício da profissão, no que tange a identificar incorreções nos procedimentos contábeis adotados pelas empresas. Também há destaque para procedimentos internacionais (FAS, USGAAP, IFRS, SarbanesOxley).

\section{Quadro 5 Conhecimentos Relativos ao Grupo 4: Contabilidade}

Conhecimento básico de contabilidade; Conhecimento de fundo contábil de consultoria de investimentos

Auxiliar nos fechamentos mensais (emissão de balancetes e/ou balanços); Criar e manter controle de inventário, protegendo os ativos da empresa; Sólidos conhecimentos em contabilidade e finanças, parte legal e TI, relacionados às rotinas em conformidade e aos relatórios; Atuar na padronização de procedimentos fiscais e societários entre empresas do mesmo grupo.

Observa-se que as exigências para atuar na área da contabilidade contemplam conhecimentos básicos relativos à formação na área. Há que se reconhecer, entretanto, a necessidade de sólidos conhecimentos em Ti e procedimentos fiscais entre empresas do mesmo grupo.

Em se tratando de aspectos fiscais, há, nesse caso, uma especialidade 
normalmente decorrente de expressiva experiência na área. O mesmo ocorre com a atividade de padronização de procedimentos.

Quadro 6 Conhecimentos Relativos ao Grupo 5: Controladoria

Conhecimento do processo de controladoria (normas de contabilidade, controles internos, custos, fiscal, reporting controle de margens e mix de produtos); Conhecimentos em planejamento tributário (emissão de relatórios, elaboração de demonstrativos, legislação tributária); Realizar revisões fiscais, levantamento de crédito e avaliação de riscos tributários; Conhecimentos em Transfer Pricing. Desenvolver análises de planejamento estratégico, tais como estudo de viabilidade econômico-financeira e validação de iniciativas financeiras; Revisar e auxiliar na implantação de procedimentos relacionados à legislação de preços de transferência; P\&L da análise da variância sobre as receitas; Participar de iniciativas de planejamento estratégico para otimizar a economia de impostos ou para minimizar a carga tributária; Preparação de budgets, forecasts e relatórios gerenciais sobre o desempenho geral da empresa para tomada de decisões; Conhecimento de modelo de negócio estruturado em incentivos fiscais; Consolidação de uma variedade de negócios para que a estrutura seja produtiva e competitiva; Conduzir, administrar e executar auditorias; Experiência em projetos de arranque em empresas multinacionais; Implantação de medidores de produtividade

Os requisitos para atuação na área de controladoria, como já esperado pela abrangência da área, são mais amplos. De fato, para atuar na área de controladoria, o profissional contábil deve desenvolver conhecimentos relativos a outras áreas de conhecimento, como administração e economia, além dos tradicionais da área contábil (CATELLI, 200I).

O conteúdo do Quadro 6 evidencia que o candidato deve ter conhecimento de diversas atividades e procedimentos, transitando pelas áreas de contabilidade societária, contabilidade de custos, finanças, impostos, gestão de projetos, gestão orçamentária, entre outras.

\section{Quadro 7 Conhecimentos Relativos ao Grupo 6: Financeira}

Conhecimento das atividades financeiras (custo de mercadoria, despesas operacionais, elaboração de demonstrativos, emissão de relatórios); Conhecimento de produtos financeiros (renda fixa, obrigações hipotecárias); Conhecimento de processos administrativos (folha de pagamento, seguro, orçamentos, TI, compras, logística); Elaboração e acompanhamento na implantação de novos projetos (análise, controle de custos, despesas operacionais); Gestão de caixa, capital de giro, tesouraria e auditoria; Gestão de faturamento, recolhimento e processamento de informações; Introdução de liquidação para subscrição/resgates diários.

Para atuação na área financeira o profissional contábil deve dominar conhecimentos relativos a transações financeiras básicas do mercado de 
capitais, de captação e aplicação, além de rotinas internas de tesouraria e gestão de capital de giro.

Além desses conhecimentos inerentes às finanças, há também exigências quanto a diversos processos administrativos, gestão de projetos e auditoria.

Quadro 8 Outros Conhecimentos e Habilidades Exigidas pelo Mercado

Fluência em Inglês, Alemão, Espanhol, Japonês, Francês ou Italiano; Alta energia, iniciativa, pró-atividade, desejo de crescer; Comprometimento, maturidade, perspicácia, estratégia; Comunicação, dinamismo, mobilidade, flexibilidade, espírito de equipe; Negociação, persuasão, empreendedorismo; Gestão de mudanças; Gestão de pessoas (liderança, motivação, organização); Relacionamento interpessoal; Trabalho em equipe, sob pressão; Visão estratégica, de negócio, foco nos resultados; Conhecimento MS Office; Conhecimento em SPED contábil e fiscal; Conhecimento nos sistemas: SAP, ERP, Datasul (implantação e parametrização).

Por fim, mas tão importante quanto às outras competências e habilidades, para atuar em qualquer área relacionada à formação contábil, é necessário apresentar distintas capacidades. Os conteúdos requeridos para preenchimento de cada oferta estão apresentados no corpo do anúncio, sem grau de importância e sem deixar claro de que forma será avaliado se o candidato possui ou não as respectivas competências e habilidades.

Observa-se que algumas exigências (pessoal, profissional e de negócio) talvez estejam além dos conteúdos possíveis de ensino pelas IEs. Entretanto, a expectativa do mercado é que o ensino, no nível que for, deve prover o futuro profissional com esses conhecimentos.

\section{ANÁLISE COMPARATIVA: CURRÍCULOS DAS IES VERSUS EXIGÊNCIAS REQUERIDAS PELO MERCADO}

Esta seção apresenta análise referente à quantidade de IEs, que ministram disciplinas que contemplam as competências e habilidades requeridas pelo mercado. Salienta-se que em nenhum momento durante a pesquisa houve a preocupação de verificar se as disciplinas são efetivamente ministradas pelas IES. Assim, esta análise baseia-se exclusivamente nas informações fornecidas pelos coordenadores dos 2I cursos que participaram da pesquisa. A análise tem a mesma sequência dos grupos e áreas estabelecidas e apresentadas no Quadro I. 
Os dados apresentados na Tabela 4 referem-se à comparação dos conhecimentos relacionados à Área Tributária.

Tabela 4 Ensino versus Mercado Grupo 1: Área Tributária

\begin{tabular}{|c|c|c|c|c|}
\hline & \multicolumn{4}{|c|}{ Quantidade de IES } \\
\hline & Adota & $\%$ & Não Adota & $\%$ \\
\hline Conhecimento das rotinas contábil e fiscal & 18 & 86 & 3 & 14 \\
\hline $\begin{array}{l}\text { Conciliar, analisar e apurar impostos diretos e indiretos, além } \\
\text { do cumprimento das obrigações acessórias }\end{array}$ & 21 & 100 & 0 & 0 \\
\hline Conhecimentos em IR, CS, PIS, COFINS, DIPJ & 21 & 100 & 0 & 0 \\
\hline $\begin{array}{l}\text { Conhecimento da tributação da zona de livre comércio de } \\
\text { Manaus }\end{array}$ & 12 & 57 & 9 & 43 \\
\hline $\begin{array}{l}\text { Cálculo de impostos/taxas/tributos, coletas e relatórios de } \\
\text { último prazo }\end{array}$ & 20 & 95 & 1 & 5 \\
\hline $\begin{array}{l}\text { Conhecimento da legislação referente a impostos diretos e } \\
\text { indiretos }\end{array}$ & 19 & 90 & 2 & 10 \\
\hline
\end{tabular}

Os conteúdos referentes à área tributária são contemplados pela maioria das instituições. No entanto, alguns dados apresentam-se relevantes: três instituições (I4\%) afirmaram não ministrar disciplinas que contemplem o conhecimento relativo às rotinas contábeis e fiscais. Embora pequeno, o número se torna significativo por tratar-se do curso de graduação em Ciências Contábeis; uma instituição (5\%) afirma a não adoção de cálculo de impostos/taxas/tributos, coleta de dados e relatórios de último prazo.

Ressalta-se que os respondentes de nove instituições, equivalente a $43 \%$ do total, afirmaram a não ocorrência de disciplinas que contemplem o ensino referente ao conhecimento da tributação da zona de livre comércio de Manaus. Esta afirmação talvez não seja significativa, pois, o conhecimento deste tipo de tributação deve possuir maior relevância para empresas que possuam algum tipo de negócio com essa região.

No que se refere aos conteúdos da área de custos, apenas uma instituição (5\%) afirmou não adotar disciplinas que contemplem o ensino do conhecimento referente a custo-padrão. As demais instituições apresentamse alinhadas às exigências requeridas pelo mercado, conforme apresentado na Tabela 5. Essa informação, apesar de restrita a apenas uma instituição, 
chama a atenção, pois custo-padrão é uma técnica de larga escala no planejamento e controle de custos (GARRISON e NOREEN, 20OI).

Tabela 5 Ensino versus Mercado Grupo 2: Área Custos

\begin{tabular}{|c|c|c|c|c|}
\hline & \multicolumn{4}{|c|}{ Quantidade de IES } \\
\hline & Adota & $\%$ & Não Adota & $\%$ \\
\hline $\begin{array}{l}\text { Controle dos custos das mercadorias e } \\
\text { despesas operacionais }\end{array}$ & 21 & 100 & 0 & 0 \\
\hline Conhecimentos em custo padrão & 20 & 95 & 1 & 5 \\
\hline
\end{tabular}

O Grupo 3, Área Auditoria, apresentou resultados significativos em três atividades específicas, relacionadas à adoção de normas nacionais e internacionais. Atualmente são muito referidas pela literatura as questões relacionadas à contabilidade internacional, principalmente a respeito da padronização das normas contábeis.

Por esta razão, é significativo que quatro instituições (19\%) informem a não adoção do ensino referente ao conhecimento da Lei Sarbanes-Oxley; oito (38\%) afirmem não ministrar disciplinas que abordem o conhecimento relativo ao FAS Io9; e uma (5\%) afirme não ministrar disciplinas referentes à USGAAP, BRGAAP e IFRS. Observa-se que todo esse conteúdo não contemplado pelo ensino das IES pesquisadas está entre aqueles considerados necessários para os contadores da atualidade, conforme enfatizado por Kounrozan (2005). Os resultados dos demais conteúdos não foram comentados porque se referem a normas muito específicas e, sendo assim, somente terão relevância para aqueles profissionais que necessitem desses conhecimentos específicos (Tabela 6). 
Tabela 6 Ensino versus Mercado Grupo 3: Auditoria

\begin{tabular}{|llllll|} 
& \multicolumn{3}{c}{ Quantidade de IES } \\
& Adota & $\%$ & Não Adota & $\%$ \\
\hline $\begin{array}{l}\text { Domínio na utilização da USGAAP, BRGAAP, IFRS } \\
\text { (consolidação, análise, conversão, relatórios para } \\
\text { investidores estrangeiros) }\end{array}$ & 20 & 95 & 1 & 5 \\
$\begin{array}{l}\text { Garantir a conformidade de procedimentos e } \\
\text { requisitos com a regulação Sarbanes-Oxley }\end{array}$ & 17 & 81 & 4 & 19 \\
\hline $\begin{array}{l}\text { Conhecimento das Normas da Comissão de Valores } \\
\text { Mobiliários (CVM) }\end{array}$ & 21 & 100 & 0 & 0 \\
\hline $\begin{array}{l}\text { Conhecimentos gerais sobre o Banco Central (BACEN) e } \\
\text { Receita Federal }\end{array}$ & 16 & 76 & 5 & 24 \\
\hline $\begin{array}{l}\text { Implantação de práticas corporativas } \\
\text { Noções de FAS109 }\end{array}$ & 15 & 71 & 6 & 29 \\
\hline \begin{tabular}{l} 
Conhecimentos em Legislação Societária \\
\hline
\end{tabular} & 21 & 62 & 8 & 38 \\
\hline
\end{tabular}

Os conteúdos relativos ao Grupo 4, Área Contabilidade, apresentam-se satisfatoriamente amparados pelos currículos utilizados nos cursos de graduação em Ciências Contábeis das IEs situadas no Rio Grande do Sul. Todas as 2I IES afirmaram a ocorrência de disciplinas de contabilidade básica e a ocorrência de disciplinas visando à formação de profissionais capazes para auxiliarem nos fechamentos mensais (emissão de balancetes e/ou balanços) das empresas. Isso é compreensível, pois o que está aqui contemplado é explicitamente inerente à função contábil básica (IUDícibus, 1993).

O fato de nove instituições (43\%) não adotarem disciplinas, que abordem conteúdo referente ao conhecimento de fundo contábil de consultoria de investimentos, já era esperado por acreditar-se que as IEs não consigam inserir em suas matrizes curriculares disciplinas que abordem conhecimentos tão específicos. Mesmo assim, destaca-se que I2 instituições (57\%) oferecem disciplinas que abordam essa temática, conforme apresentado na Tabela 7. 
Tabela 7 Ensino versus Mercado Grupo 4: Contabilidade

\begin{tabular}{|c|c|c|c|c|}
\hline & \multicolumn{4}{|c|}{ Quantidade de IES } \\
\hline & Adota & $\%$ & Não Adota & $\%$ \\
\hline Conhecimento básico de contabilidade & 21 & 100 & 0 & 0 \\
\hline $\begin{array}{l}\text { Conhecimento de fundo contábil de consultoria de } \\
\text { investimentos }\end{array}$ & 12 & 57 & 9 & 43 \\
\hline $\begin{array}{l}\text { Auxiliar nos fechamentos mensais (emissão de balancetes e/ } \\
\text { ou balanços) }\end{array}$ & 21 & 100 & 0 & 0 \\
\hline $\begin{array}{l}\text { Criar e manter controle de inventário que protegem os } \\
\text { ativos da empresa }\end{array}$ & 20 & 95 & 1 & 5 \\
\hline $\begin{array}{l}\text { Sólidos conhecimentos em contabilidade e finanças, } \\
\text { parte legal e TI, relacionados a rotinas em conformidade e } \\
\text { relatórios }\end{array}$ & 18 & 86 & 3 & 14 \\
\hline $\begin{array}{l}\text { Atuar na padronização de procedimentos fiscais e } \\
\text { societários entre empresas do mesmo grupo }\end{array}$ & 17 & 81 & 4 & 19 \\
\hline
\end{tabular}

Com relação aos conteúdos requeridos pelo Grupo 5, Controladoria, todas as instituições de ensino superior apresentaram-se alinhadas às exigências do mercado no que se refere á abordagem dos conhecimentos relativos ao processo de controladoria (normas de contabilidade, controles internos, custos, fiscal e mix de produtos), conforme referenciado por Nascimento e Reginato (2007) O mesmo ocorre com referência à preparação de budgets, forecasts e relatórios gerenciais sobre desempenho geral da empresa.

Analisando os dados da Tabela 8, percebe-se que alguns outros temas apresentam resultados significativos com relação à não adoção de disciplinas que abordem os respectivos conhecimentos. De fato, I4 instituições (67\%) não contemplam o ensino referente a projetos de arranque em empresas multinacionais; II (52\%) não abordam $P \mathcal{F} L$ da análise de variância sobre as receitas; nove (43\%) não tratam do conhecimento de modelos de negócio estruturado em incentivos fiscais. 
Tabela 8 Ensino versus Mercado Grupo 5: Área Controladoria

\begin{tabular}{|c|c|c|c|c|}
\hline & \multicolumn{4}{|c|}{ Quantidade de IES } \\
\hline & Adota & $\%$ & Não Adota & $\%$ \\
\hline $\begin{array}{l}\text { Conhecimento de processo de controladoria (normas de } \\
\text { contabilidade, controles internos, custos, fiscal, } \\
\text { reporting controle de margens e mix de produtos) }\end{array}$ & 21 & 100 & 0 & 0 \\
\hline $\begin{array}{l}\text { Conhecimentos em planejamento tributário } \\
\text { (emissão de relatórios, elaboração de demonstrativos, } \\
\text { legislação tributária) }\end{array}$ & 20 & 95 & 1 & 5 \\
\hline $\begin{array}{l}\text { Realizar revisões fiscais, levantamento de crédito e } \\
\text { avaliação de riscos tributários }\end{array}$ & 18 & 86 & 3 & 14 \\
\hline Conhecimentos em Transfer Pricing & 14 & 67 & 7 & 33 \\
\hline $\begin{array}{l}\text { Desenvolver análises de planejamento estratégico: } \\
\text { estudo de viabilidade econômico-financeira e } \\
\text { validação de iniciativas financeiras }\end{array}$ & 21 & 100 & 0 & 0 \\
\hline $\begin{array}{l}\text { Revisar e auxiliar na implantação de procedimentos } \\
\text { relacionados à legislação de preços de transferência }\end{array}$ & 14 & 57 & 7 & 33 \\
\hline P\&L da análise da variância sobre as receitas & 10 & 48 & 11 & 52 \\
\hline $\begin{array}{l}\text { Participar de iniciativas de planejamento estratégico para } \\
\text { otimizar a economia de impostos ou para minimizar a } \\
\text { carga tributária }\end{array}$ & 19 & 90 & 2 & 10 \\
\hline $\begin{array}{l}\text { Preparação de budgets, forecasts e } \\
\text { relatórios gerenciais sobre o desempenho geral da empresa } \\
\text { para tomada de decisões }\end{array}$ & 21 & 100 & 0 & 0 \\
\hline $\begin{array}{l}\text { Conhecimento de modelo de negócio estruturado em } \\
\text { incentivos fiscais }\end{array}$ & 12 & 57 & 9 & 43 \\
\hline $\begin{array}{l}\text { Consolidação de uma variedade de negócios para que } \\
\text { a estrutura seja produtiva e competitiva }\end{array}$ & 15 & 71 & 6 & 29 \\
\hline Conduzir, administrar e executar auditorias & 21 & 100 & 0 & 0 \\
\hline $\begin{array}{l}\text { Experiência em projetos de arranque em } \\
\text { empresas multinacionais }\end{array}$ & 7 & 33 & 14 & 67 \\
\hline Implantação de medidores de produtividade & 15 & 71 & 6 & 29 \\
\hline
\end{tabular}

Dentro do conteúdo do Grupo 6, referente à área financeira, três ocorrências apresentaram resultados preocupantes: duas instituições (Io\%) afirmaram a não oferta de disciplinas que contemplem o conhecimento das atividades financeiras (custo de mercadoria, despesas operacionais, elaboração de demonstrativos, emissão de relatórios); cinco (24\%) não desenvolvem o conhecimento relativo à elaboração e ao acompanhamento na implantação 
de novos projetos (análise, controle de custos, despesas operacionais); e duas (ıо\%) não abordam o ensino referente à gestão de caixa, ao capital de giro e à tesouraria.

A não ocorrência de disciplinas que abordem os conteúdos acima citados é preocupante, porque os atributos questionados referem-se a conhecimentos básicos relativos à área financeira, conforme Assaf Neto (2003) Os demais elementos não foram comentados porque não apresentaram resultados de grandes distorções, conforme apresentado na Tabela 9.

Tabela 9 Ensino versus Mercado Grupo 6: Financeira

\begin{tabular}{|lcccc|} 
& \multicolumn{3}{c}{ Quantidade de IES } \\
& Adota & $\%$ & Não Adota & $\%$ \\
\hline $\begin{array}{l}\text { Conhecimento das atividades financeiras } \\
\text { (custo de mercadoria, despesas operacionais, } \\
\text { elaboração de demonstrativos, emissão de relatórios) }\end{array}$ & 19 & 90 & 2 & 10 \\
\hline $\begin{array}{l}\text { Conhecimento de produtos financeiros } \\
\text { (renda fixa, obrigações hipotecárias) }\end{array}$ & 18 & 86 & 3 & 14 \\
\hline $\begin{array}{l}\text { Conhecimento de processos administrativos (folha de } \\
\text { pagamento, seguro, orçamentos, TI, compras, logística) }\end{array}$ & 18 & 86 & 3 & 14 \\
\hline $\begin{array}{l}\text { Elaboração e acompanhamento na implantação de novos } \\
\text { projetos (análise, controle de custos, despesas operacionais) }\end{array}$ & 16 & 76 & 5 & 24 \\
\hline $\begin{array}{l}\text { Gestão de caixa, capital de giro, tesouraria e auditoria } \\
\text { Gestão de faturamento, recolhimento e }\end{array}$ & 19 & 90 & 2 & 10 \\
\hline $\begin{array}{l}\text { processamento de informações } \\
\text { Introdução de liquidação para subscrição/resgates diários }\end{array}$ & 9 & 43 & 12 & 29 \\
\hline
\end{tabular}

Por fim, tem-se o Grupo 7, referente a outras competências e habilidades requeridas pelo mercado, cujos resultados são apresentados na Tabela Io. A fluência em língua estrangeira não é adotada como conteúdo de disciplina obrigatória por nenhuma das IEs pesquisadas. De outra parte, elas oferecem o ensino relativo à língua estrangeira como disciplina optativa ou disciplina de atividade complementar.

Os conhecimentos relativos aos sistemas informatizados também se apresentam majoritariamente tratados nas disciplinas dos cursos, apesar da não adoção ainda apresentar-se expressiva, ao redor de $30 \%$. Isso é relevante, pois, na atualidade esse recurso é um requisito relevante no mercado. 
Destaca-se ainda, outro conjunto que reúne iniciativas como comunicação, dinamismo, mobilidade, flexibilidade, espírito de equipe, aproximadamente no mesmo nível daquelas relacionadas a sistemas e à informática.

Ressalta-se, de modo geral, que a importância atribuída às competências e habilidades reunidas no grupo 7 (Tabela Io) ainda carece de maiores avanços, apesar de presença elevada nas IEs. De qualquer forma, fica evidente que a maioria das IEs ainda continua mais fortemente concentrada na formação

Tabela 10 Ensino versus Mercado Grupo: 7 Outras Habilidades

\begin{tabular}{|c|c|c|c|c|}
\hline & \multicolumn{4}{|c|}{ Quantidade de IES } \\
\hline & Adota & $\%$ & Não Adota & $\%$ \\
\hline $\begin{array}{l}\text { Fluência em Inglês, Alemão, Espanhol, Japonês, } \\
\text { Francês ou Italiano }\end{array}$ & 0 & 0 & 21 & 100 \\
\hline Alta energia, iniciativa, pró-atividade, desejo de crescer & 13 & 62 & 8 & 38 \\
\hline Comprometimento, maturidade, perspicácia, estratégia & 14 & 67 & 7 & 33 \\
\hline $\begin{array}{l}\text { Comunicação, dinamismo, mobilidade, } \\
\text { flexibilidade, espírito de equipe }\end{array}$ & 14 & 67 & 7 & 33 \\
\hline Negociação, persuasão, empreendedorismo & 14 & 67 & 7 & 33 \\
\hline Gestão de mudanças & 10 & 48 & 11 & 52 \\
\hline Gestão de pessoas (liderança, motivação, organização) & 12 & 57 & 9 & 43 \\
\hline Relacionamento interpessoal & 12 & 57 & 9 & 43 \\
\hline Trabalho em equipe, sob pressão & 12 & 57 & 9 & 43 \\
\hline Visão estratégica, de negócio, foco nos resultados & 14 & 67 & 7 & 33 \\
\hline Conhecimento MS Office & 9 & 43 & 12 & 57 \\
\hline Conhecimento em SPED contábil e fiscal & 15 & 71 & 6 & 29 \\
\hline $\begin{array}{l}\text { Conhecimento nos sistemas: SAP, ERP, Datasul } \\
\text { (implantação e parametrização) }\end{array}$ & 15 & 71 & 6 & 29 \\
\hline
\end{tabular}




\section{CONSIDERAÇÕES FINAIS}

Por meio deste estudo, buscou-se analisar o alinhamento existente entra as exigências de ofertas de trabalho e o conteúdo das matrizes curriculares, utilizadas por IEs situadas no Rio Grande do Sul e que oferecem cursos de graduação em Ciências Contábeis.

Em resposta ao objetivo geral do estudo, pode-se concluir que a análise realizada dos conteúdos declarados pelos coordenadores de cursos evidencia majoritário atendimento que o ensino oferecido pelas IES cumpre em relação às demandas de mercado para o profissional contábil da atualidade. De outra parte, também se deve destacar que algumas competências e habilidades ainda não são atendidas por expressiva parcela das IES pesquisadas. Essa conclusão fica mais clara quando os resultados são analisados dentro das respectivas categorias estabelecidas no estudo.

$\mathrm{Na}$ Categoria I (Tributária), consta apenas um elemento com expressivo nível de não atendimento, equivalente a $43 \%$ da amostra, referente à tributação das atividades da zona de livre comércio de Manaus. Na Categoria 2 (Custos), a menos detalhada pelos anúncios de ofertas, as demandas de mercado são plenamente atendidas pelas IEs.

$\mathrm{Na}$ Categoria 3 (Auditoria), já se observa maior quantidade de conhecimentos que, embora atendidos por majoritária parcela das IES, ainda carecem de maiores avanços em parcela destacada das instituições pesquisadas. Noções de FAS IO9 (38\%), implantação de práticas corporativas (29\%) e conhecimentos gerais sobre BACEN e Receita Federal (24\%) são as mais relevantes. Na Categoria 4 (Contabilidade), tem-se o mesmo posicionamento da Categoria I (Tributária), ou seja, apenas um tipo de conhecimento, referente ao fundo contábil de consultoria de investimento, deixa a desejar por $43 \%$ da amostra.

$\mathrm{Na}$ Categoria 5 (Consultoria), tem-se expressiva quantidade de conhecimentos não contemplados pela estrutura adotada pelas IEs em relação ao requisitado pelo mercado. Os principais conhecimentos ainda carecendo de melhora são os seguintes: Experiência em projetos de arranque em empresas multinacionais [startup], com 67\%; P\&L e análise da 
variância sobre as receitas, com $52 \%$; Conhecimento de modelos de negócios estruturados em incentivos fiscais, com $43 \%$; procedimentos relacionados à legislação de preços de transferência [transfer pricing], com 33\%; implantação de medidores de produtividade e consolidação de negócios com estrutura produtiva e competitiva, com $29 \%$.

Na Categoria 6 (Financeira), três tipos de conhecimentos se destacam pelo não atendimento integral pelas IEs. O primeiro refere-se às operações de liquidação para subscrição e resgates diários, com $57 \%$; o segundo referese à gestão de faturamento, recolhimento e processamento de informações, com $29 \%$; o terceiro, com $24 \%$, refere-se à elaboração e ao acompanhamento da implantação de novos projetos (análise, controle de custos, despesas operacionais).

Por fim, tem-se a Categoria 7 (Outras Habilidades), mais relacionada a competências e habilidades pessoais e não ao foco técnico da profissão contábil. Os destaques acerca do não atendimento pelas IES recaem sobre: fluência em idioma exterior (I00\%); conhecimento em мsOffice (57\%); gestão de mudanças (52\%); gestão de pessoas; relacionamento interpessoal; trabalho em equipe; trabalho sob pressão, todos eles com $43 \%$, da alta energia, iniciativa, produtividade e desejo de crescer, com $38 \%$ da amostra. Além desses há também: visão estratégica, de negócio, foco nos resultados; comprometimento, maturidade, perspicácia estratégica; comunicação, dinamismo, mobilidade, flexibilidade e espírito de equipe; negociação, persuasão, empreendedorismo, todos eles com $33 \%$. Observa-se que a maior expressividade de não atendimento pelas IES centra-se nessa Categoria 7 , a que menos abrange conhecimentos sobre a técnica e procedimentos contábeis. Parece ser aqui onde há maior necessidade de avanços nos cursos regulares de graduação em Ciências Contábeis.

É comum, durante o desenvolvimento de estudos desta natureza, identificarem-se focos de estudos com potencial de avançar o conhecimento sobre a temática pesquisada. No caso deste estudo, duas situações se apresentam: (a) pesquisar e rediscutir a abrangência e profundidade dos conteúdos curriculares dos cursos oferecidos pelas IEs, principalmente sobre os conhecimentos detalhados na Categoria 7 deste estudo; (b) 
realizar estudos de profundidade, talvez na modalidade de estudos de casos múltiplos, a fim de investigar com mais detalhes a efetiva oferta dos conhecimentos que o mercado demanda e, a princípio, disponibilizados pelos cursos. Nesta última sugestão, recomenda-se que a pesquisa seja realizada diretamente com os alunos para conhecer a ótica deles a respeito da preparação e conteúdos recebidos durante o curso. 


\section{REFERENNCIAS}

ALBU, C. N.; ALBU, N.; FAFF, R.; HODGSON, A. The changing role of accountants in a transition economy: evidence from Romania. Annales Universitatis Apulensis Series Economica, v. 1, n. 10, p. 5-10, 2008. Disponível em: http:// econpapers.repec.org/article/alujournl/v_3a1_3ay_3a2008_3ai_3a10_3ap_3a5.htm. Acesso em: 20/09/2011.

ALBU, C. N.; ALBU, N.; FAFF, R.; HODGSON, A.. Accounting competencies and the changing role of accountants in emerging economies: the case of Romania. Accounting in Europe, v. 8, n. 2, p. 155-184, 2011.

ASSAF NETO. Finanças corporativas e valor. São Paulo: Atlas, 2003.

ATTIE, W. Auditoria: conceitos e aplicações. 3. ed. São Paulo: Atlas, 1998.

BRASIL. Decreto Lei 6141, de 28.12.1943. Lei Orgânica do Ensino Comercial. Disponível em: $<$ http://www6.senado.gov.br/legislacao/DetalhaDocumento. action?id=6717>. Acesso em: 15/09/2011.

BRASIL. Decreto Lei 7988, de 22/09/1945. Dispõe sobre o ensino de Ciências Econômicas e de Ciências Contábeis e Atuariais. Diário Oficial da União, Seção I, 20/09/1945, p. 15.297.

BRASIL. Decreto Lei 9295, de 27/05/1946. Cria o Conselho Federal de Contabilidade, define as atribuições do Contador e do Guarda-livros, e dá outras providências. Disponível em: <http://www.crc.org.br/crcrj/crc.asp>. Acesso em: 25/07/2011.

BRASIL - Ministério da Educação. Resolução CFE 03/92, de 03/10/1992. Fixa os mínimos de conteúdo e duração do curso de graduação em Ciências Contábeis. Brasília, DF, Diário Oficial da União, 03/10/1992, Seção 1, p. 2107.

BRASIL. Lei 9394, de 20/12/1996, Estabelece as Diretrizes e Bases da Educação Nacional. Disponível em: <http://portal.mec.gov.br/seesp/arquivos/pdf/lei9394_ldbn1. pdf>. Acesso em: 31/08/2011.

BRASIL. Resolução 6/2004, editada em 10/03/2004 pela Câmara de Educação Superior do Conselho Nacional de Educação. Institui as diretrizes curriculares nacionais do curso de graduação em Ciências Contábeis, bacharelado, e dá outras providências. Diário Oficial da União no 63 de 01/04/2004, Seção 1, página 28.

BRASLAVSKY, C. Re-Haciendo escuelas: hacia um nuevo paradigma em la education latinoamericana. Buenos Aires: Santillna, 1999.

BURNS, J.; BALDVINSDOTTIR, G. An institutional perspective of accountants new roles: the interplay of contradictions and praxis. European Accounting Review, v. 14, n. 4, p. 715-757, 2005.

BYRNE, S.; PIERCE, B. Towards a more comprehensive understanding of the roles of management accountants. The European Accounting Review, v. 16, n. 3, p. 469498, 2007. 
CARDOZO, J. L.; SOUZA, M. A.; ALMEIDA, L. B. Perfil do contador na atualidade: um estudo exploratório. BASE, v. 3, n. 3, p. 275-284, set/dez. 2006.

CATELLI, A. Controladoria. São Paulo: Atlas, 2001.

CEDRO, M. Pesquisa social e fontes orais: particularidades da entrevista como procedimento metodológico qualitativo. Revista Perspectivas Sociais, v.1, n. 1, p. 125-135, março 2011.

CONSENZA, J. P. Perspectiva para a profissão contábil num mundo globalizado: um estudo a partir da experiência brasileira. Revista Brasileira de Contabilidade, n. 30, p. 43-54, jul 2001.

CORDEIRO, J. S.; DUARTE, A.M. P. O Profissional contábil diante da nova realidade.Qualit@s-Revista Eletrônica, v. 1, n. 1, p. 68-96, 2006.

EDITORA ABRIL. Revista Exame. Edições anos 2008 e 2009. São Paulo: Editora Abril, 2008 e 2009.

FOGAÇA, A. A educação e reestruturação produtiva. In: FOGAÇA, Azuete, Política de emprego no Brasil. Campinas: Instituto de Economia UNICAMP, 1998, p. 30-45.

GARRISON, R. H.; NOREEN, E. W. Contabilidade Gerencial. Rio de Janeiro: LTC, 2001.

GIL, A. C. Métodos e Técnicas de Pesquisa Social. São Paulo: Atlas, 1999.

GONDIN, S. M. G. Perfil profissional e mercado de trabalho: relação com a formação acadêmica pela perspectiva de estudantes universitários. Estudos de Psicologia, v. 7, n. 2, p. 299-309, 2002.

IUDÍCIBUS, S. Teoria da Contabilidade. 3. ed. São Paulo: Atlas, 1993.

KOUNROUZAN, M. C. O perfil do profissional contábil. 2.005. Disponível em: $<$ http://www.oswaldocruz.br/download/artigos/social17.pdf >. Acesso em: 18/05/2009.

LAFFIN, M. Ensino de contabilidade: componentes e desafios. Contabilidade Vista \& Revista, v. 13, n. 3, p. 9-20, dez. 2007.

LEITE, C. E. B. A evolução das ciências contábeis no Brasil. Rio de Janeiro: FGV, 2005 .

LUFT, C. P. Minidicionário Luft. 20. Ed. São Paulo: Ática, 2000.

MACEDO, L. Eixos teóricos que estruturam o ENEM: conceitos principais. Brasília: MEC/INEP, 1999.

MANSOURI, A.; PIRAYESCH, R.; SALEHI, M. Audit competence and audit quality: case in emerging economy. International Journal of Business and Management, v. 4, n. 2, p. 17-25, February 2009.

MARION, J. C.; SANTOS, M. C. Os dois lados de uma profissão. Contabilidade Vista e Revista, v. 11, n. 2, p. 3-9, ago. 2000.

MARION, J. C.; SANTOS, M. C. Preparando-se para a profissão do futuro. 
Contabilidade Vista \& Revista, v. 9, n. 1, p. 14-21, mar. 1998.

MORAES, D. D.; MADEIRA, G. J. A contabilidade como sistema de apoio à decisão. Contabilidade Vista e Revista, v. 13, n. 3, p. 93-104, dez. 2002.

NASCIMENTO, A.; REGINATO, L. São Paulo: Atlas, 2007.

NASCIMENTO, C. L. Qualidade do ensino superior em Ciências Contábeis: um diagnóstico nas instituições localizadas na região norte do estado do Paraná. BASE, v. 2, n. 3, p. 155-166, set/dez 2005.

OTT, E.; CUNHA, J. V. A.; CORNACCHIONE JR, E. B.; DE LUCA, M. M. M. Relevância dos conhecimentos, habilidades e métodos instrucionais na perspectiva de estudantes e profissionais da área contábil: estudo comparativo internacional. Revista Contabilidade \& Finanças, v. 22, n. 57, p. 338-356, 2011.

PELEIAS, I. R.; GUIMARÃES, P. C.; SILVA, D.; ORNELAS, M. M. G. Identificação do perfil profissiográfico do profissional de contabilidade requerido pelas empresas, em anúncios de emprego na região metropolitana de São Paulo. $B A S E$, v. 5, n. 2, p. 131-141, mai/ago. 2008.

PELEIAS, I. R.; SILVA, G. P.; SEGRETI, J. B.; CHIROTTO, A. R. Evolução do ensino da contabilidade no Brasil: Uma análise histórica. Revista Contabilidade \& Finanças, edição 30 anos dourado, p. 19-32, jun. 2007.

PEREIRA FILHO, A. D. As decisões empresariais e o sistema de informações contábeis: uma abordagem com vistas à análise de performance financeira. Contabilidade Vista e Revista, Belo Horizonte, v. 10, n. 1, p. 3-12, mar. 1999. PERRENOUD, P. Construir as competências desde a escola. Porto Alegre: Artes Médicas Sul, 1999.

PERRENOUD, P. Dez novas competências para ensinar. Porto Alegre: Artes Médicas Sul, 2000.

PIRES, C. B. A formação e a demanda de trabalho do contador na região metropolitana de Porto Alegre - RS. Rio Grande do Sul, 2008. Dissertação (Mestrado em Ciências Contábeis) - Universidade do Vale do Rio dos Sinos UNISINOS.

RIBEIRO, M. A. O contador “profissional” e o contador "aplicado". Revista do Conselho Regional de Contabilidade do Rio Grande do Sul, Porto Alegre, n. 5, p. 1-5, dez. 2007.

RICHARDSON, R. J. Pesquisa social: métodos e técnicas. 3. ed. São Paulo:, Atlas, 1999.

ROE, R. A. What makes a competent psychologist? European Psychologist, v. 7, n. 3, p. 192-202, September 2002.

ROPÉ, F.; TANGUY, L. (Org.). Saberes e competências: o uso de tais noções na escola e na empresa. Campinas: Papirus, 1997. 
SCHWEZ, N. Responsabilidade social: meta e desafio profissional da contabilidade para o próximo milênio. $R B C$, ano. XXX, n. 130, jul/ago. 2001.

SILVA, A. C. R. Metodologia da pesquisa aplicada à contabilidade: orientações de estudo, projetos, artigos, relatórios, monografias, dissertações, teses. São Paulo: Atlas, 2006.

SILVA, L. A. Garcez. A contabilidade e sua verdadeira função. Revista do Conselho Regional de Contabilidade do Rio Grande do Sul, Porto Alegre, n. 9, p. 1-4, dez. 2008.

TCHEOU, H. Avaliação do ensino de contabilidade nos cursos de administração de empresas na cidade de São Paulo. São Paulo, 2002. Dissertação (Mestrado em Administração) FECAP - Fundação Escola de Comércio Álvares Penteado.

TEODORESCU, T. Competence versus competency: what is the difference? Performance Improvement, v. 45, n. 10, p. 27-30, nov/dec 2006.

VALENTE, S. M. P.. Competências e habilidades. 2003. Disponível em: <http:// www.opas.org.br/medicamentos/site/UploadArq/COMPET\%C3\%8ANCIAS_E_ HABILIDADES-_TEXTO_FORMATADO.pdf>. Acesso em: 15/09/2011.

WESTERA, W. Competences in education: a confusion of tongues. Journal of Curriculum Studies, v. 33, n. 1, p. 75-88, 2001.

WOLCOTT, S. K.; BARIL, C. P.; CUNNINGHAM, B. Towards a development approach to pedagogy in accounting education. AICPA, 2000. Disponível em: $<$ http://www.wolcottlynch.com/Downloadable_Files/AAA_Pedagogy_ Report_000731.pdf>. Acesso em: 15/09/2011. 


\section{APÊNDICE A - INSTRUMENTO DE COLETA DE DADOS}

$\begin{array}{lll}\begin{array}{l}\text { Grupos dos Atributos/Habilidades Requisitados } \\ \text { pelo Mercado }\end{array} & \begin{array}{l}\text { Disciplina que } \\ \text { aborda o conteúdo } \\ \text { indicado }\end{array} & \begin{array}{l}\text { Semestre/Período } \\ \text { do curso que } \\ \text { ocorre a disciplina }\end{array}\end{array}$

Grupo 1: Conteúdos referentes aos Tributos

Conhecimento das rotinas contábil e fiscal

Conciliar, analisar e apurar impostos diretos e indiretos, além do cumprimento das obrigações acessórias

Conhecimentos em IR, CS, PIS, COFINS, DIPJ

Conhecimento da tributação da zona livre de comércio de Manaus

Cálculo de impostos/taxas/tributos, coletas e relatórios de último prazo

Conhecimento da legislação referente a impostos diretos e indiretos

Grupo 2: Conteúdos referentes aos Custos

Controle dos custos das mercadorias e despesas operacionais

Conhecimentos em custo padrão standard

Grupo 3: Conteúdos referentes a Normas Nacionais e Internacionais

Domínio na utilização da USGAAP, BRGAAP, IFRS (consolidação, análise, conversão, relatórios para investidores estrangeiros)

Garantir a conformidade de procedimentos e requisitos com a regulação Sarbanes-Oxley

Conhecimento das Normas da Comissão de valores Mobiliários (CVM)

Conhecimentos gerais sobre o Banco Central

(BACEN) e Receita Federal

Implantação de práticas corporativas

Noções de FAS109

Conhecimentos em Legislação Societária

Grupo 4: Conteúdos referentes à Contabilidade Societária

Conhecimento básico de contabilidade

Conhecimento de fundo contábil de consultoria de investimentos

Auxiliar nos fechamentos mensais (emissão de balancetes e/ou balanços) 


\begin{tabular}{|c|c|c|}
\hline $\begin{array}{l}\text { Grupos dos Atributos/Habilidades Requisitados } \\
\text { pelo Mercado }\end{array}$ & $\begin{array}{l}\text { Disciplina que } \\
\text { aborda o conteúdo } \\
\text { indicado }\end{array}$ & $\begin{array}{l}\text { Semestre/Periodo } \\
\text { do curso que } \\
\text { ocorre a disciplina }\end{array}$ \\
\hline \multicolumn{3}{|l|}{$\begin{array}{l}\text { Criar e manter controle de inventário, protegendo } \\
\text { os ativos da empresa }\end{array}$} \\
\hline \multicolumn{3}{|l|}{$\begin{array}{l}\text { Sólidos conhecimentos em contabilidade e } \\
\text { finanças, parte legal e TI, relacionados às rotinas em } \\
\text { conformidade e aos relatórios }\end{array}$} \\
\hline \multicolumn{3}{|l|}{$\begin{array}{l}\text { Atuar na padronização de procedimentos fiscais e } \\
\text { societários entre empresas do mesmo grupo }\end{array}$} \\
\hline \multicolumn{3}{|l|}{ Grupo 5: Conteúdos referentes à Controladoria } \\
\hline \multicolumn{3}{|l|}{$\begin{array}{l}\text { Conhecimento do processo de controladoria } \\
\text { (normas de contabilidade, controles internos, custos, } \\
\text { fiscal, reporting controle de margens e mix de } \\
\text { produtos) }\end{array}$} \\
\hline \multicolumn{3}{|l|}{$\begin{array}{l}\text { Conhecimentos em planejamento tributário } \\
\text { (emissão de relatórios, elaboração de } \\
\text { demonstrativos, legislação tributária) }\end{array}$} \\
\hline \multicolumn{3}{|l|}{$\begin{array}{l}\text { Realizar revisões fiscais, levantamento de crédito e } \\
\text { avaliação de riscos tributários }\end{array}$} \\
\hline \multicolumn{3}{|l|}{ Conhecimentos em Transfer Pricing } \\
\hline \multicolumn{3}{|l|}{$\begin{array}{l}\text { Desenvolver análises de planejamento estratégico, } \\
\text { tais como estudo de viabilidade econômico- } \\
\text { financeira e validação de iniciativas financeiras }\end{array}$} \\
\hline \multicolumn{3}{|l|}{$\begin{array}{l}\text { Revisar e auxiliar na implantação de procedimentos } \\
\text { relacionados à legislação de preços de transferência }\end{array}$} \\
\hline \multicolumn{3}{|l|}{ P\&L da análise da variância sobre as receitas } \\
\hline \multicolumn{3}{|l|}{$\begin{array}{l}\text { Participar de iniciativas de planejamento } \\
\text { estratégico para otimizar a economia de impostos } \\
\text { ou para minimizar a carga tributária }\end{array}$} \\
\hline \multicolumn{3}{|l|}{$\begin{array}{l}\text { Preparação de budgets, forecasts e relatórios } \\
\text { gerenciais sobre o desempenho geral da empresa } \\
\text { para tomada de decisões }\end{array}$} \\
\hline \multicolumn{3}{|l|}{$\begin{array}{l}\text { Conhecimento de modelo de negócio estruturado } \\
\text { em incentivos fiscais }\end{array}$} \\
\hline \multicolumn{3}{|l|}{$\begin{array}{l}\text { Consolidação de uma variedade de negócios para } \\
\text { que a estrutura seja produtiva e competitiva }\end{array}$} \\
\hline \multicolumn{3}{|l|}{ Conduzir, administrar e executar auditoria } \\
\hline \multicolumn{3}{|l|}{$\begin{array}{l}\text { Experiência em projetos de arranque em empresas } \\
\text { multinacionais }\end{array}$} \\
\hline \multicolumn{3}{|l|}{ Implantação de medidores de produtividade } \\
\hline Grupo 6: Conteúdos referentes a Finanças & & \\
\hline
\end{tabular}




$\begin{array}{lll}\begin{array}{l}\text { Grupos dos Atributos/Habilidades Requisitados } \\ \text { pelo Mercado }\end{array} & \begin{array}{l}\text { Disciplina que } \\ \text { aborda o conteúdo } \\ \text { indicado }\end{array} & \begin{array}{l}\text { Semestre/Período } \\ \text { ocorre a disciplina }\end{array}\end{array}$

Conhecimento das atividades financeiras (custo de mercadoria, despesas operacionais, elaboração de demonstrativos, emissão de relatórios)

Conhecimento de produtos financeiros (renda fixa, obrigações hipotecárias)

Conhecimento de processos administrativos (folha de pagamento, seguro, orçamentos, TI, compras, logística)

Elaboração e acompanhamento na implantação de novos projetos (análise, controle de custos, despesas operacionais)

Gestão de caixa, capital de giro, tesouraria e auditoria

Gestão de faturamento, recolhimento e processamento de informações

Introdução de liquidação para subscrição/resgates

diários

\section{Grupo 7: Outras Competências e Habilidades}

Fluência em Inglês, Alemão, Espanhol, Japonês,

Francês ou Italiano

Alta energia, iniciativa, pró-atividade, desejo de crescer

Comprometimento, maturidade, perspicácia, estratégia

Comunicação, dinamismo, mobilidade, flexibilidade, espírito de equipe

Negociação, persuasão, empreendedorismo

Gestão de mudanças

Gestão de pessoas (liderança, motivação, organização)

Relacionamento interpessoal

Trabalho em equipe, sob pressão

Visão estratégica, de negócio, foco nos resultados

Conhecimento MS Office

Conhecimento em SPED contábil e fiscal

Conhecimento nos sistemas: SAP, ERP, Datasul

(implantação e parametrização) 


\section{DADOS DOS AUTORES}

MARCOS ANTONIO DE SOUZA* marcosas@unisinos.br Doutor em Controladoria e Contabilidade pela FEA/USP

Instituição de vinculação: Universidade do Vale do Rio dos Sinos

São Leopoldo/RS - Brasil

Áreas de interesse em pesquisa: Ensino e Pesquisa em Contabilidade;

Gestão Custos e Controladoria.

* Endereço: Avenida Unisinos, 950 - Ciências Econômicas

Cristo Rei São Leopoldo/RS 93022-000

CAROLINE DA SILVA VERGILINO carolvergili@yahoo.com.br

Bacharel em Contabilidade pela UNISINOS

Instituição de vinculação: Universidade do Vale do Rio dos Sinos

São Leopoldo/RS - Brasil

Áreas de interesse em pesquisa: Ensino e Pesquisa em Contabilidade e Gestão de Custos. 